\title{
Properties of Young Guapuruvu (Schizolobium parahyba) Wood from a Forest Recovery Area
}

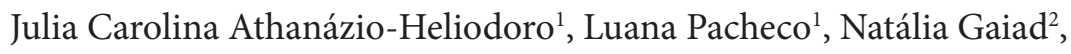 \\ Hernando Alphonso Lara-Palma ${ }^{1}$, Adriano Wagner Ballarin ${ }^{1}$ \\ ${ }^{1}$ Faculdade de Ciências Agronômicas, Universidade Estadual Paulista - UNESP, Botucatu/SP, Brasil \\ ${ }^{2}$ Universidade Federal do Paraná - UFPR, Curitiba/PR, Brasil
}

\begin{abstract}
Guapuruvu is one of the fastest growing Atlantic Forest species. It is also considered one of most important species in forest recovery areas, starting to compete with other individuals during the second stage of succession, as well as showing a capacity to be harvested and processed at this stage, after fulfilling its function as a pioneer. There are no conclusive studies about the technological potential of the wood from the young guapuruvu trees characteristic of this context. The present study evaluated the physical-mechanical properties and quality of guapuruvu wood from young trees (15 years old) from forest recovery areas in accordance with NBR 7190. The presence of tension wood did not influence the homogeneity of the wood, which is classified as strength class C20 - hardwood, with characteristic strength of $21.47 \mathrm{MPa}$ in compression parallel to the grain, characteristic tension strength of $23.12 \mathrm{MPa}$ parallel to grain and modulus of elasticity (MOE) of 5,925 MPa. Basic and apparent densities were $290 \mathrm{~kg} / \mathrm{m}^{3}$ and $336 \mathrm{~kg} / \mathrm{m}^{3}$ respectively. However, its low density did not lead to low mechanical strength. The high ratio between the values of its mechanical properties and apparent density, added to its high homogeneity - despite the presence of tension wood - demonstrated the good quality of its wood.
\end{abstract}

Keywords: mechanical properties, Schizolobium parahyba, wood quality. 


\section{INTRODUCTION AND OBJECTIVES}

The Brazilian species Schizolobium parahyba (Vell) Blake, (guapuruvu) - Fabaceae (Leguminosae Caesalpinioideae) - found throughout the Atlantic Forest region is classified as a forest succession pioneer, presenting fast growth, reaching $30 \mathrm{~m}$ of height and $100 \mathrm{~cm}$ of DBH - diameter at breast high - during its adult stage, with an average volume increment between 45 and $60 \mathrm{~m}^{3}$.ha $\mathrm{h}^{-1}$.year ${ }^{-1}$. It is considered one of the 12 most important species for reforestation and is widely used in the recovery of degraded areas due to its characteristics as a pioneer species (Salgado et al., 1989; Lima et al., 2000). It is one of the fastest growing native species, has cylindrical and erect bole, marked by scars and has few branches. Its bark is grey and the wood is white-straw with composed leaves up to one meter long (Carvalho, 2005).

In forest succession, after a beneficial period of shadowing for the secondary, late and climax species, the still young guapuruvu starts to compete with them for water, light and nutrients, thus harming their development and tending to naturally disappear from the forest system. However, if it is gradually removed using forest management, without damaging regeneration of the understory, an environment presenting faster secondary succession development is created by means of a natural induction of native vegetation regeneration. This removal would also provide a financial return for the investor or landowner, through the potential sale of guapuruvu wood. Additionally, the introduction of alternative species, such as fast-growing native species may help to supply the increasing demand for wood, as well as reducing pressure on natural forests (Brienza et al., 2008).

In order to find the best use for wood from young guapuruvu trees, some physical-mechanical properties must be considered. However, there is little research in the literature about this subject. Pioneering studies of the technological potential of guapuruvu were undertaken during the 70's, showing the species' potential to produce plywood, where it was found that the low density of the material did not lead to a proportional decrease in the quality of mechanical properties (Richter et al., 1975). More recently, the quality of its anatomical elements for producing paper and cellulose was demonstrated (Nisgoski et al., 2012). It was found that the species creates annual growth rings delimited by narrow parenchymal strips correlated with the beginning of the dry season (Marcati et al., 2008). There is high correlation between the width of its growth rings and environmental factors while greater development is related to precipitation (Latorraca et al., 2015) and to higher levels of shading (Caron et al., 2010). Studies have shown that guapuruvu wood is more susceptible to color change than other species (Mattos et al., 2016). There are also studies about the medicinal uses of extracts from its leaves (Vale et al., 2011; Mendes et al., 2008).

From a physical-mechanical point of view, the study by Mainieri \& Chimelo (1989) evaluated some properties of guapuruvu wood (at 15\% EMC Equilibrium moisture content) without mentioning the age or site conditions of the plantation. It is also known that increases in density along the radius in guapuruvu are non-linear and regulated by age and not by the dimensions of the tree. This behavior may cause some risk of structural failure in the individual despite the density increasing with age, reinforcing what was a precarious bole (Williamson et al., 2012).

Finally, it is also possible to show that Schizolobium amazonicum (Huber ex Ducke) Barneby wood, popularly known as paricá, is very similar to guapuruvu wood. This species is already commercially cultivated in northern Brazil, with a total of 87,500 ha of plantation in 2013 (ABRAF, 2013). Its physical-mechanical properties were evaluated by Almeida et al. (2013a, b) who classified the wood of this species in strength class C20 - hardwood, according to NBR 7190 (ABNT, 1997). The use of preserving treatments with $\mathrm{CCB}$ in autoclave did not change any of the studied properties of the species, with the exception of hardness parallel to the grain, which decreased by $28.9 \%$ (Icimoto et al., 2013).

The main objective of this study was to evaluate the physical-mechanical properties and the structural classification of the wood from young (15-year old) guapuruvu (Schizolobium parahyba (Vell.) Blake) trees from a forest recovery area and to determinate if its low density is a limiting factor on its mechanical performance.

\section{MATERIAL AND METHODS}

\subsection{Sampling and material preparation}

Six 15-year old trees were harvested from a forest recovery area located in the Experimental Farm Lageado - College of Agricultural Sciences - UNESP - Botucatu Campus - SP $\left(22^{\circ} 50^{\prime} \mathrm{S} ; 48^{\circ} 25^{\prime} \mathrm{W}\right)-700$ m altitude. 
This reforestation was established in 1997 in a slightly inclined $2500 \mathrm{~m}^{2}$ area using a direct seeding system and minimal tillage for the plantation of several species including guapuruvu. The degraded area has annual average precipitation and temperature of $1470 \mathrm{~mm}$ and $19.4^{\circ} \mathrm{C}$, respectively. Its soil is classified as red Nitosoil (terra roxa) with excellent fertility and good physical properties, but with a tendency to compaction (Engel \& Parrota, 2000). A 1.20m-long log measured from below breast height was sawn from each tree and a $3 \mathrm{~cm}$-thick disk from the top of each log (breast height) was used to perform basic and apparent density testing and a $7 \mathrm{~cm}$-thick disk was used to determine Janka hardness and to evaluate for the presence of tension wood. From the remaining log, an $8 \mathrm{~cm}$-thick center board was taken from the region containing the pith, to determine other physical-mechanical properties. As a prophylactic treatment, boards and disks were sprayed with Osmose insecticide CP50 (2.5\%) and Osmotox Plus fungicide (4\%) immediately after sawing.

In general, from each radial position around the pith of the central board, two clear specimens were produced in accordance with NBR 7190 (ABNT, 1997) to perform the mechanical tests (strength and stiffness in compression parallel and normal to grain, tension parallel and normal to grain, shear strength and hardness), totaling 24 test specimens for each test (6 trees $\times 4$ specimens per tree). Exceptionally, bending specimens and shrinkage specimens were produced with lower dimensions $(2 \mathrm{~cm} \times 2 \mathrm{~cm} \times 46$ $\mathrm{cm}$ and $2 \mathrm{~cm} \times 3 \mathrm{~cm} \times 5 \mathrm{~cm}$, respectively). Hardness tests were performed directly on the disks. All samples were acclimatized (climate-controlled room with 21 ${ }^{\circ} \mathrm{C}$ and $65 \%$ of relative humidity), to reach $12 \%$ of EMC - Equilibrium moisture content.

\subsection{Physical and mechanical tests}

Basic density was determined by gravimetric method (hydrostatic balance method) using the ratio between the dry mass and saturated volume of the specimens. The evaluation of the apparent density of wood was performed by the immersion method (variation in net weight) using the ratio of its mass and volume at current moisture levels (Vital, 1984).

Mechanical tests were performed with a computercontrolled DL30000 model $300 \mathrm{kN}$ eletromechanical testing machine - EMIC in the Laboratory of Materials Testing - Department of Rural Engineering from the
College of Agricultural Sciences - FCA, UNESP Botucatu - SP, Brazil, according to prescriptions of NBR 7190 (ABNT, 1997). Results of strength and elastic properties (modulus of elasticity) were corrected to the EMC (12\%) using a 3\% correction coefficient (of variation per $1 \%$ of $\mathrm{MC}$ variation) for strength values and $2 \%$ for elastic properties (Figure 1).

\subsection{Presence of tension wood}

The presence of tension wood was analyzed by the occurrence of fibers with gelatinous layers (Bowyer et al., 2007). Two radial strips were selected, one from the major radius of a tree with unbalanced radius and the other from a tree with balanced ones (trees one and two, respectively). Specimens were obtained from four regions located in growth rings four and seven (heartwood), 11 (transition zone) and 14 (sapwood) - Figure 2.

Semi-permanent laminas were made according to the method described in Bukatsh (1972), modified by Kraus \& Arduin (1997). Anatomical analysis was performed using a Axioshop 40 Zeiss microscope and laminas were photographed with camera AxioCam MRC - Zeiss, using the program AxioVision LE 4.6.

\subsection{Statistical analysis of results}

Physical and mechanical wood properties were reported by central tendency (mean) and dispersion (coefficient of variation). Additionally, strength values of the sample (considered as the set of the six trees) were reported in terms of characteristic values, estimated using the equation recommended by standard NBR 7190 (ABNT, 1997; Eufrade et al., 2015).

Comparison of results obtained between opposite radius - bending, hardness and shrinkage - was performed using paired sample T-test, specific for data dependent between itself. Statistical software Origin PRO 8 was used and a 5\% significance level adopted.

\section{RESULTS AND DISCUSSION}

\subsection{Presence of tension wood}

The trees in this study had tension wood, evidenced by the presence of gelatinous layers in fibers in both types of woods (tension and opposite wood) from both trees analyzed (Figure 3). 


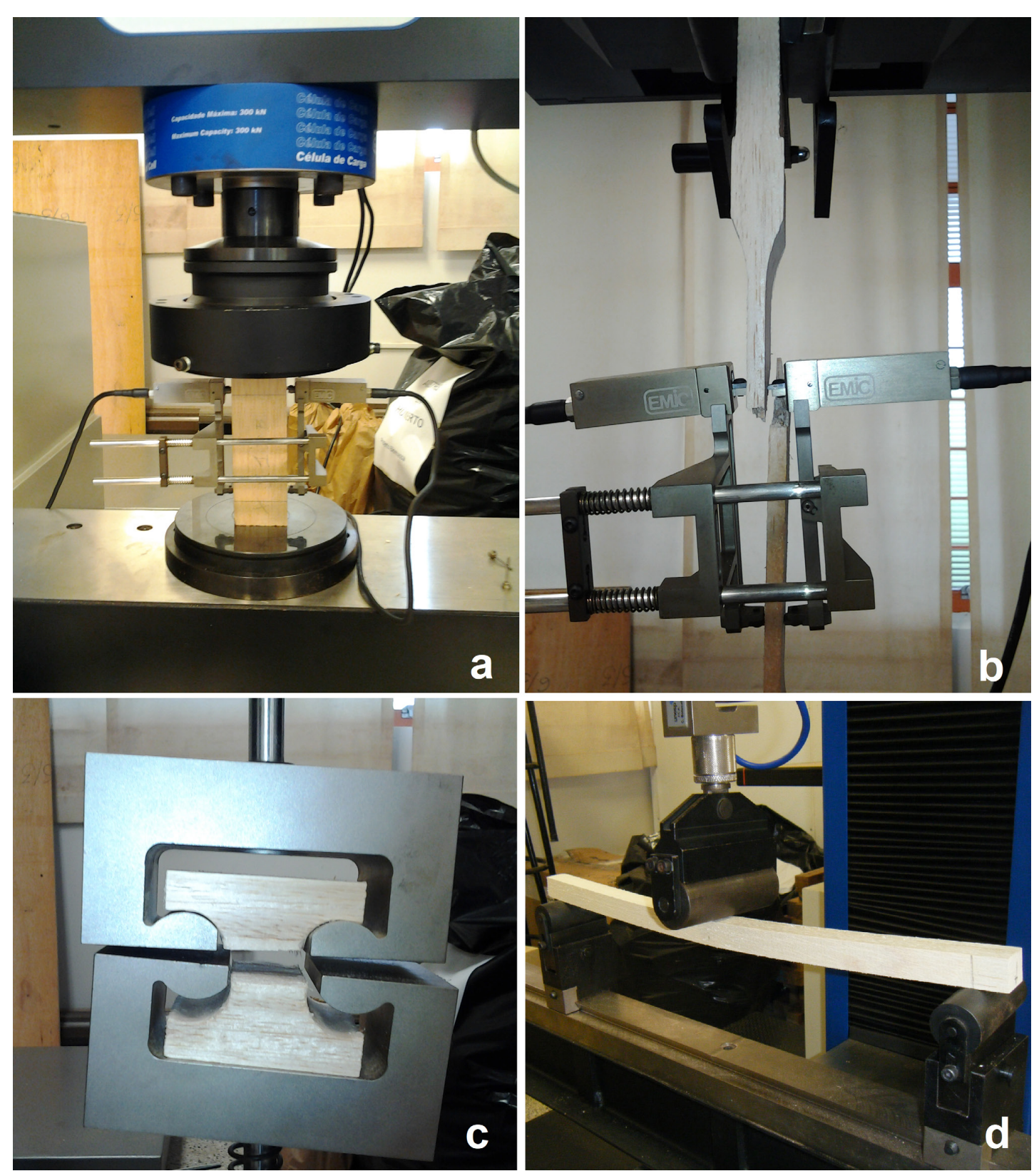

Figure 1. Overview of some mechanical tests of guapuruvu wood; (a) compression strength parallel to grain; (b) tension strength parallel to grain; (c) tension strength perpendicular to grain; (d) bending.

Figure 2. Radial strip of tree with location of samples for evaluating the presence of tension wood: (a) and (b) heartwood samples; (c) transition zone sample; (d) sapwood sample. 
The presence of tension wood in guapuruvu trees was expected, because the experimental area is inclined (Engel \& Parrota, 2000). Cultivation in sloping areas and the fast development of guapuruvu trees, which causes significant growth stresses, are the causes of the development of tension wood (Sousa, 2004; Bowyer et al., 2007). The presence of tension wood is considered a disadvantage by the industry, since it may cause changes in the natural characteristics of the wood and, also increases the variability of these properties (Du \& Yamamoto, 2007). Individuals with tension wood tend to have greater growth stresses and different physical and mechanical properties, when compared with the opposite wood (Ruelle et al., 2011), resulting in losses, during the industrial process, and difficulties in classification.

\subsection{Physical and mechanical properties of wood}

Mean basic density of guapuruvu wood (Table 1) was $290 \mathrm{~kg} / \mathrm{m}^{3}$ (C.V. $\left.=9.96 \%\right)$ and apparent density was $336 \mathrm{~kg} / \mathrm{m}^{3}$ (C.V. = 10.34\%).

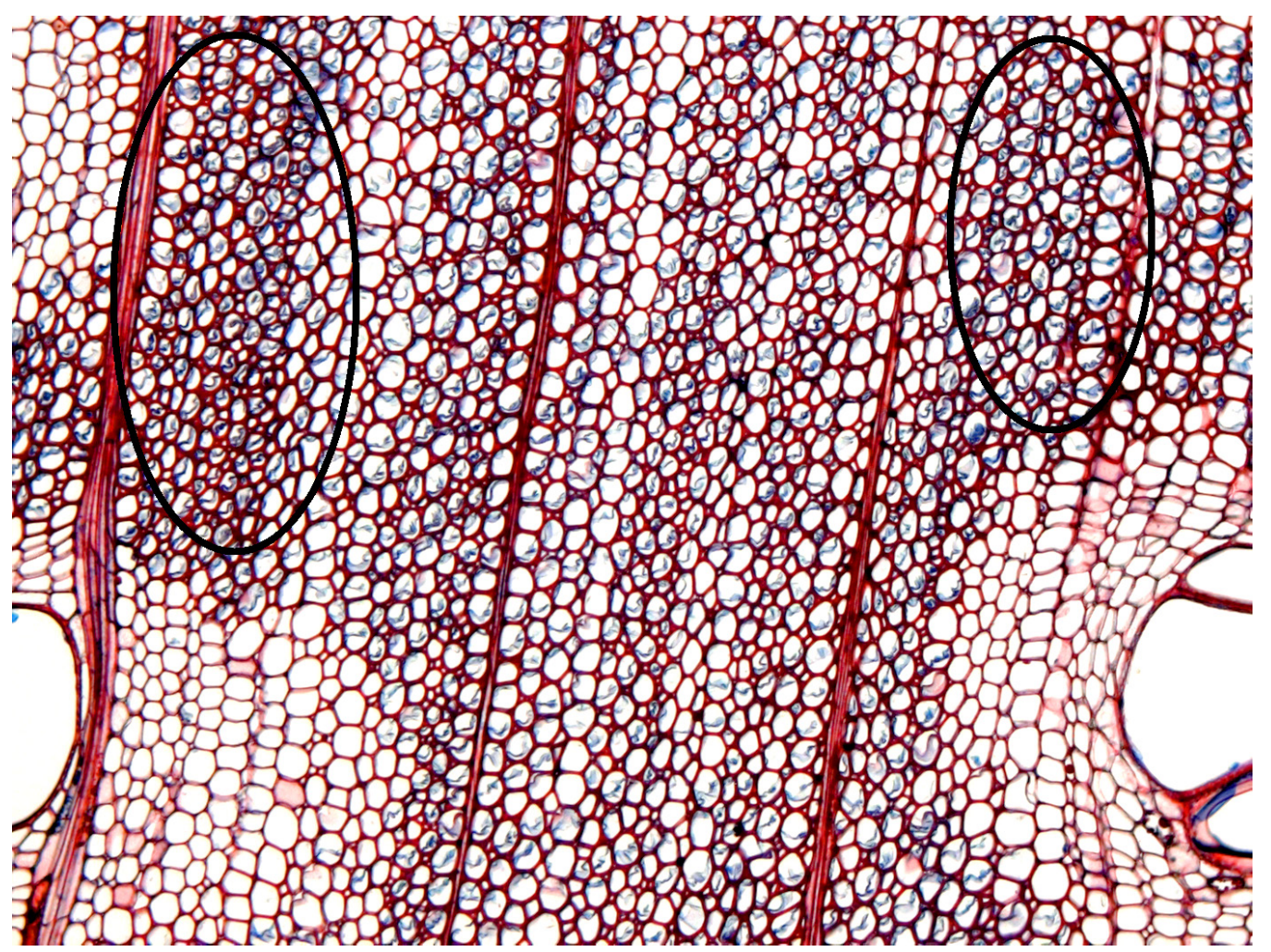

Figure 3. Tension wood identified by the presence of fibers with gelatinous layers in astra blue (highlighted) on the wood of Schizolobium parahyba.

Table 1. Physical properties of guapuruvu wood (Schizolobium parahyba).

\begin{tabular}{|c|c|c|c|c|c|c|c|}
\hline & $\rho_{b}{ }^{1}$ & $\rho_{12}{ }^{2}$ & $\beta \mathbf{r}^{3}$ & $\beta \mathbf{t}^{4}$ & $\beta 1^{5}$ & $\beta v^{6}$ & Anis. ${ }^{7}$ \\
\hline & \multicolumn{2}{|c|}{$\left(\mathrm{kg} / \mathrm{m}^{3}\right)$} & \multicolumn{5}{|c|}{ (\%) } \\
\hline Minimum & 256 & 291 & 1.81 & 4.85 & 0.07 & 7.61 & 1.88 \\
\hline Maximum & 321 & 388 & 4.67 & 12.27 & 0.86 & 20.22 & 3.67 \\
\hline Arith. Mean ${ }^{8}$ & 290 & 336 & 2.69 & 7.24 & 0.34 & 11.19 & 2.74 \\
\hline S. Dev. ${ }^{9}$ & 28.85 & 34.74 & 0.60 & 1.28 & 0.15 & 2.19 & 0.39 \\
\hline C. Var. ${ }^{10}$ & 9.96 & 10.34 & 22.20 & 17.64 & 44.50 & 19.55 & 14.24 \\
\hline
\end{tabular}

${ }^{1}$ Basic density; ${ }^{2}$ Density at $12 \%$ EMC; ${ }^{3}$ Radial shrinkage; ${ }^{4}$ Tangential shrinkage; ${ }^{5}$ Longitudinal shrinkage; ${ }^{6}$ Volumetric shrinkage; ${ }^{7}$ Anisotropy index; ${ }^{8}$ Arithmetic mean; ${ }^{9}$ Standard deviation; ${ }^{10}$ Coefficient of variation. 
Arithmetic means of radial, tangential, longitudinal and volumetric shrinkages were 2.69, 7.24, 0.34 and $11.19 \%$, respectively. According to the classification scale for wood shrinkage of Zhang \& Koubaa (2001), these shrinkages were classified as very low (radial) and low (tangential and volumetric). Despite this, the anisotropy index, indicating an imbalance between the dimensional variations of the wood, which are evaluated by the ratio between tangential and radial shrinkages, was 2.74. This value is a high index (Nock et al., 1975), evidencing the tendency to split and warp, already found by other researchers (LTM, 2009; Jankowsky et al., 1990), ruling out its use in certain applications (such as windows and frames) and making it recommendable for use in civil construction (provided that the mechanical requirements are met).

In the national context, the compression parallel to grain is the most important property since it is considered a pure test, as well as presenting a good correlation with almost all of the mechanical properties of the wood. For the Brazilian standard, this strength is the parameter that defines structural classification of this material. Guapuruvu wood showed a mean strength of $22.81 \mathrm{MPa}$ in compression parallel to grain. The modulus of elasticity was $5,728 \mathrm{MPa}$ in this property (Table 2).

Bending strength ( $\mathrm{f}_{\mathrm{M}}$ or MOR - modulus of rupture) and modulus of elasticity in bending $\left(\mathrm{E}_{\mathrm{M}}\right.$ or $\left.\mathrm{MOE}\right)$ are properties adopted for strength classification of wood by some international standards (ASTM, EN, e.g.). Modulus of rupture (MOR) of guapuruvu was 40.47 $\mathrm{MPa}$ and the modulus of elasticity (MOE) was $5,925 \mathrm{MPa}-$ Table 2.

For all properties, in general, the coefficients of variation of properties were considered medium (around 15\%) according to Pimentel-Gomes' (1985) classification - Tables 1 and 2. The lower values (smaller than $10 \%$ ) were those for the compression parallel to grain and basic and apparent densities, evidencing the homogeneity of the wood for important properties, even given the presence of tension wood. Only the coefficients of variation of the tension strength parallel to grain and of the MOE in compression perpendicular to grain were considered high (over 20\%). These higher values may be partially attributed to the difficulty to perform those particular tests.

The values observed here for the properties were generally higher than those reported by Mainieri \& Chimelo (1989) - adjusted to 12\% EMC - except for the modulus of rupture in bending (Table 3 ). When compared with paricá (S. amazonicum), the mechanical performance of guapuruvu was inferior, however very close, especially the strength in compression parallel to grain. Compared with another alternative species ( $H$. brasiliensis) the performance was also inferior; however $H$. brasiliensis trees are harvested over 25 years old - adult trees - and the commercial diameters at breast height $(\mathrm{DBH})$ at those ages are no greater than, in general, $45 \mathrm{~cm}$ (Leonello, 2011) while S. parahyba reached DBH around $48 \mathrm{~cm}$ at only 15 years.

Guapuruvu wood was classified as structural class $\mathrm{C} 20$ - hardwood $\left(\mathrm{f}_{\mathrm{c} 0, \mathrm{k}} \geq 20 \mathrm{MPa}\right)$ even with an apparent density at $12 \% \mathrm{EMC}$ of $336 \mathrm{~kg} / \mathrm{m}^{3}$ that is about half the reference value for this class according to the NBR 7190 standard (ABNT, 1997) - Table 4 demonstrating the good mechanical performance of the species at 15 years old.

The ratio between the modulus of elasticity in compression in the directions perpendicular and parallel to grain $\left(\mathrm{E}_{\mathrm{c} 90} / \mathrm{E}_{\mathrm{c} 0}\right)$ was 0.086 , higher than the

Table 2. Mechanical properties of guapuruvu wood (Schizolobium parahyba).

\begin{tabular}{|c|c|c|c|c|c|c|c|c|c|c|c|}
\hline & $\mathrm{E}_{\mathrm{c} 0}^{1}$ & $f_{c 0}{ }^{2}$ & $E_{t 0}^{3}$ & $f_{t 0}^{4}$ & $\mathrm{E}_{M}{ }^{5}$ & $f_{M}{ }^{6}$ & $\mathrm{f}_{\mathrm{v}}{ }^{7}$ & $\mathrm{E}_{\mathrm{c90}}{ }^{8}$ & $f_{c 90}{ }^{9}$ & $f_{t 90}{ }^{10}$ & $f_{H}^{11}$ \\
\hline & \multicolumn{11}{|c|}{ (MPa) } \\
\hline Minimum & 4,532 & 17.27 & 4,184 & 18.59 & 3,598 & 27.94 & 3.68 & 257 & 2.12 & 1.98 & 12.50 \\
\hline Maximum & 6,902 & 26.83 & 7,574 & 50.45 & 7,999 & 55.04 & 7.62 & 901 & 3.34 & 4.65 & 29.40 \\
\hline Arith. Mean & 5,728 & 22.81 & 6,172 & 36.50 & 5,925 & 40.47 & 5.35 & 497 & 2.46 & 3.55 & 18.89 \\
\hline S. Dev. ${ }^{12}$ & 718 & 2.12 & 981 & 8.35 & 1,022 & 6.26 & 0.67 & 172 & 0.33 & 0.65 & 3.65 \\
\hline C. Var. $^{13}$ & 12.54 & 8.61 & 15.89 & 22.88 & 17.25 & 15.46 & 12.50 & 34.55 & 13.36 & 18.16 & 19.33 \\
\hline
\end{tabular}

${ }^{1}$ Modulus of elasticity in compression parallel to grain; ${ }^{2}$ Compression strength parallel to grain; ${ }^{3}$ Modulus of elasticity in tension parallel to grain; ${ }^{4}$ Tension strength parallel to grain; ${ }^{5}$ Modulus of elasticity in static bending; ${ }^{6}$ Modulus of rupture in bending; ${ }^{7}$ Shear strength parallel to grain; ${ }^{8}$ Modulus of elasticity in compression perpendicular to grain; ${ }^{9}$ Compression strength perpendicular to grain; ${ }^{10} \mathrm{Tension}$ strength perpendicular to grain; ${ }^{11} \mathrm{Janka}$ hardness; ${ }^{12} \mathrm{Standard}$ deviation; ${ }^{13} \mathrm{Coefficient}$ of variation. 
Table 3. Comparison of guapuruvu (Schizolobium parahyba) properties and other species.

\begin{tabular}{|c|c|c|c|c|c|c|c|c|c|c|}
\hline \multirow{3}{*}{ Species } & \multicolumn{2}{|c|}{ Physical properties } & \multicolumn{7}{|c|}{ Mechanical properties } & \multirow{3}{*}{$\operatorname{Ref}^{10}$} \\
\hline & $\rho_{12}^{1}$ & $\rho_{b}^{2}$ & $f_{c 0}{ }^{3}$ & $\mathrm{E}_{\mathrm{c} 0}^{4}$ & $f_{t 90} 5$ & $f_{v 0}{ }^{6}$ & $f_{M}{ }^{7}$ & $\mathrm{E}_{\mathrm{M}}{ }^{8}$ & $f_{H}{ }^{9}$ & \\
\hline & \multicolumn{2}{|c|}{$\left(\mathrm{kg} / \mathrm{m}^{3}\right)$} & \multicolumn{7}{|c|}{$(\mathrm{MPa})$} & \\
\hline \multirow{2}{*}{ S. parahyba } & 336 & 290 & 22.81 & 5,728 & 3.55 & 5.35 & 40.47 & 5,925 & 18.89 & a \\
\hline & 314 & N.A. & 20.95 & 5,640 & 3.10 & 5.01 & 45.10 & 4,970 & 16.13 & b \\
\hline S. amazonicum & 370 & 300 & 27.00 & 7,320 & 1.55 & 8.00 & 50.00 & 8,900 & N.A. & c \\
\hline H. brasiliensis & 681 & 550 & 41.90 & 9,920 & 3.22 & 7.72 & N.A. & N.A. & N.A. & d \\
\hline
\end{tabular}

The values presented in the table are mean values. N.A. - not available. ${ }^{1}$ Density at $12 \%$ EMC; ${ }^{2}$ Basic density; ${ }^{3}$ Compression strength parallel to grain; ${ }^{4}$ Modulus of elasticity in compression parallel to grain; ${ }^{5}$ Tension strength perpendicular to grain; ${ }^{6}$ Shear strength;

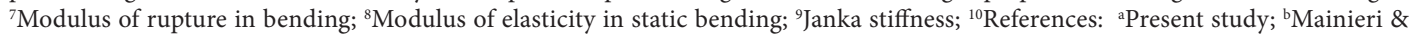
Chimelo (1989), 'Almeida et al. (2013a, b); ${ }^{\mathrm{d}}$ Eufrade et al. (2015)

Table 4. Physical-mechanical properties of Schizolobium parahyba and the referential for structural class C20 hardwood (NBR 7190, ABNT, 1997).

\begin{tabular}{|c|c|c|c|c|c|c|c|c|}
\hline \multirow{2}{*}{\multicolumn{2}{|c|}{ Physical properties }} & \multicolumn{6}{|c|}{ Mechanical properties } & \multirow{3}{*}{$\operatorname{Ref}^{3}$} \\
\hline & & \multicolumn{4}{|c|}{ Parallel to grain } & \multicolumn{2}{|c|}{ Perpendicular to grain } & \\
\hline $\boldsymbol{\rho}_{\mathrm{ap} 12 \%}$ & $\rho_{\text {bas }}$ & $f_{c 0, k}$ & $f_{t 0, k}$ & $\mathrm{f}_{\mathrm{v} 0, \mathrm{k}}$ & $\mathbf{f}_{\mathrm{M}, \mathrm{k}}$ & $\mathrm{f}_{\mathrm{c} 90, \mathrm{k}}$ & $f_{t 90, k}$ & \\
\hline \multicolumn{2}{|c|}{$\left(\mathrm{kg} / \mathrm{m}^{3}\right)^{1}$} & \multicolumn{4}{|c|}{$(\mathrm{MPa})^{2}$} & \multicolumn{2}{|c|}{$(\mathrm{MPa})^{2}$} & \\
\hline 336 & 290 & 21.47 & 23.12 & 5.07 & 34.64 & 2.36 & 3.02 & a \\
\hline 650 & 500 & 20.00 & 26.00 & 4.00 & 26.00 & 5.00 & N.A. & $\mathrm{b}$ \\
\hline
\end{tabular}

N.A. - not available; ${ }^{1}$ Mean values; ${ }^{2}$ Characteristic values; ${ }^{3}$ References: ${ }^{2}$ Present study; ${ }^{b}$ Reference values presented by NBR 7190 for structural class C20 - hardwood (ABNT, 1997).

reference suggested by NBR 7190 (0.05). The ratio between modulus of elasticity in static bending and in compression parallel $\left(\mathrm{E}_{\mathrm{M}} / \mathrm{E}_{\mathrm{co}}\right)$ was 1.03. Sales (1996) also reported equality between these moduli, although NBR 7190 (ABNT, 1997) suggests the theoretical ratio of 0.85 .

The ratio between characteristic strengths in shear and in compression parallel to grain $\left(\mathrm{f}_{\mathrm{v} 0, \mathrm{k}} / \mathrm{f}_{\mathrm{c} 0, \mathrm{k}}\right)$ was 0.23 , higher than the reference value suggested by NBR 7190 (0.12) - Table 5. The ratio between characteristic strength in compression perpendicular and parallel to grain $\left(\mathrm{f}_{\mathrm{c} 90, \mathrm{k}} / \mathrm{f}_{\mathrm{c} 0, \mathrm{k}}\right)$ was 0.11 , different from the reference value adopted by the Brazilian standard (0.25), however Kretschmann (2010) found a mean ratio of 0.10, similar to the one obtained here.

One aspect to highlight, evidencing the good performance of guapuruvu wood, is the high ratio between its mechanical properties and apparent density - specific strength (Table 5). This parameter, assumed to be a quality index when comparing species with distinct apparent densities (Buksnowitz et al., 2012) demonstrates the differentiated behavior of guapuruvu: although its wood is light, it is also relatively resistant.
It is possible to observe values always higher than the theoretical references proposed by NBR 7190 (ABNT, 1997) for class $C 20$ (Tables 4 and 5) and higher than the values obtained by Nogueira (1991) for Eucalyptus spp. species where the maximum index observed for specific strength in compression parallel to grain was 5.40 for Eucalyptus citriodora (Corymbia citriodora) while for S. parahyba, this ratio was 6.39 .

Despite the fast growth of guapuruvu wood, results obtained for specimens on two opposite positions around the pith (tension and opposite wood) did not differ for paired sample T-test $(\mathrm{p}<0.05)$, showing that the presence of tension wood had no influence on the quality or homogeneity of guapuruvu wood (Table 6).

In summary, considering the classification of wood from young (15-year old) guapuruvu trees as class C20 - hardwood for NBR 7190 (ABNT, 1997), it is possible to state that, despite its low density, the species has technological potential, presenting commercial utility for lightweight civil construction, especially in secondary elements (internal structural, decorative and internal of general utility - paneling and other woodwork), for temporary use (construction boards, 
Table 5. Relations of Schizolobium parahyba and the theoretical referential for structural class C20 - hardwood (NBR 7190, ABNT, 1997).

\begin{tabular}{cccccc}
$\frac{\boldsymbol{f}_{c 0, \boldsymbol{k}} \times 100}{\rho_{a p}}$ & $\frac{\boldsymbol{f}_{\boldsymbol{v} 0, \boldsymbol{k}} \times 100}{\rho_{a p}}$ & $\frac{\boldsymbol{f}_{c 90, \boldsymbol{k}}}{\boldsymbol{f}_{c 0, \boldsymbol{k}}}$ & $\frac{\boldsymbol{f}_{\boldsymbol{t} 0, \boldsymbol{k}}}{\boldsymbol{f}_{c 0, \boldsymbol{k}}}$ & $\frac{\boldsymbol{f}_{\boldsymbol{v} 0, \boldsymbol{k}}}{\boldsymbol{f}_{c 0, \boldsymbol{k}}}$ & Ref $^{1}$ \\
6.39 & 1.51 & 0.11 & 1.07 & 0.23 & $\mathrm{a}$ \\
4.00 & 0.80 & 0.25 & 1.30 & 0.12 & $\mathrm{~b}$ \\
\hline
\end{tabular}

${ }^{1}$ References: a Present study; ${ }^{\text {R}}$ Reference values presented by NBR 7190 for structural class C20 - hardwood (ABNT, 1997).

Table 6. Physical-mechanical properties (median) of Schizolobium parahyba in tension and opposite wood.

\begin{tabular}{|c|c|c|c|c|c|c|c|}
\hline \multirow{3}{*}{ Wood } & \multicolumn{3}{|c|}{ Mechanical Properties } & \multicolumn{4}{|c|}{ Physical properties } \\
\hline & $\mathbf{E}_{M}^{1}$ & $\mathrm{f}_{\mathrm{M}}{ }^{2}$ & $f_{H}^{3}$ & $\boldsymbol{\beta}_{\mathrm{t}}^{4}$ & $\beta_{\mathrm{r}}^{5}$ & $\beta_{\mathrm{v}}{ }^{6}$ & Anisot. ${ }^{7}$ \\
\hline & \multicolumn{3}{|c|}{ (MPa) } & \multicolumn{4}{|c|}{ (\%) } \\
\hline Opposite & 5,909 & 40.38 & 19.35 & 7.41 & 2.73 & 11.42 & 2.76 \\
\hline Tension & 5,938 & 40.55 & 18.49 & 7.09 & 2.65 & 10.98 & 2.72 \\
\hline
\end{tabular}

Medians in the same column are not statistically different (T-paired test; $\mathrm{p}<0.05$ ); ${ }^{1}$ Modulus of elasticity in static bending; ${ }^{2}$ Modulus of rupture in bending; ${ }^{3}$ Janka hardness; ${ }^{4}$ Tangential shrinkage; ${ }^{5}$ Radial shrinkage; ${ }^{6}$ Volumetric shrinkage; ${ }^{7}$ Anisotropy index.

crates) and for plywood boards (for inner parts of furniture and cabinets, ceiling and siding) (Nogueira, 1991; IPT, 2009).

\section{CONCLUSION}

Wood from young (15-year old) guapuruvu trees (Schizolobium parahyba (Vell.) Blake) from forest recovery areas was classified in structural class C20 (NBR, 7190) - hardwood. At the same time, its low density does not lead to low mechanical strength. The high ratio between its mechanical property values and apparent density, added to its high homogeneity - despite the presence of tension wood - demonstrate the good quality of the wood.

\section{SUBMISSION STATUS}

Received: 15 mar., 2017

Accepted: 26 july, 2017

\section{CORRESPONDENCE TO}

\section{Julia Carolina Athanázio-Heliodoro}

Faculdade de Ciências Agronômicas, Universidade Estadual Paulista - UNESP Rua José Barbosa de Barros, 1780, Fazenda Lageado, CEP 18610-307, Botucatu, SP, Brasil e-mail: juliaheliodoro@hotmail.com

\section{FINANCIAL SUPPORT}

Fundação de Amparo à Pesquisa do Estado de São Paulo (Grant/Award Number: 2013/13432-6).

\section{REFERENCES}

Almeida DH, Calil C Jr, Scaliante RM, Macedo LB, Macedo AN, Dias AA et al. Full characterization of wood from the amazon species Paricá in peaces of structural dimensions. Revista Árvore 2013a; 37(6): 1175-1181. http://dx.doi. org/10.1590/S0100-67622013000600019.

Almeida DH, Cavalheiro RS, Scaliante RM, Christoforo AL, Calil C Jr, Rocco Lahr FA. Full characterization of strength properties of Schizolobium amazonicum wood for timber structures. IACSIT International Journal of Engineering and Technology 2013b; 13(6): 97-100.

Associação Brasileira de Normas Técnicas - ABNT. NBR 7190: projetos de estruturas de madeira. Rio de Janeiro: ABNT; 1997.

Associação Brasileira de Produtores de Florestas Plantadas - ABRAF. Anuário estatístico ano base 2012. Brasília: ABRAF; 2013.

Bowyer JL, Shmulsky R, Haygreen JG. Forest products \& wood science: an introduction. 5th ed. Oxford: Blackwell Publishing; 2007. 558 p.

Brienza S Jr, Pereira JF, Yared JAG, Mourão M Jr, Gonçalves DA, Galeão RR. Recovery of degraded areas based on energy-timber forest production system: cost indicators, productivity and income. Revista Amazônia Ciência e Desenvolvimento 2008; 4(7): 197-219. 
Bukatsh F. Benerkemgem zeir doppelfarbeing astrablausafranina. Microkosmos 1972; 61: 255-256.

Buksnowitz C, Evans R, Muller U, Teischinger A. Indented rings (hazel growth) of Norway spruce reduce anisotropy of mechanical properties. Wood Science and Technology 2012; 46(6): 1239-1246. http://dx.doi.org/10.1007/ s00226-012-0480-0.

Caron BO, Souza VQ, Cantarelli EB, Manfron PA, Behling A, Eloy E. Growth in a seedling nursery of Schizolobium parahyba (vell.) S. F. Blake submitted to levels of shading. Ciência Florestal 2010; 20(4): 683-689.

Carvalho PER. Guapuruvu. Colombo: Embrapa Florestas; 2005. 10 p. (Circular Técnica; no. 104).

Du S, Yamamoto F. An overview of the biology of reaction wood formation. Journal of Integrative Plant Biology 2007; 49(2): 131-143. http://dx.doi.org/10.1111/j.17447909.2007.00427.x.

Engel VL, Parrota JA. Restauração de ecossistemas florestais. Agroecologia Hoje 2000; 1(4): 22-23.

Eufrade HJ Jr, Ohto JM, Silva LL, Lara Palma HA, Ballarin AW. Potential of rubberwood (Hevea brasiliensis) for structural use after the period of latex extraction: a case study in Brazil. Journal of Wood Science 2015; 61(4): 384-390. http://dx.doi.org/10.1007/s10086-015-1478-7.

Icimoto FH, Ferro FS, Varanda LD, Souza AM, Almeida $\mathrm{DH}$, Christoforo AL et al. Physical and mechanical properties of paricá wood species treated with CCB preservative. International Journal of Materials Engineering 2013; 3(4): 8-86.

Instituto de Pesquisas Tecnológicas - IPT. Madeira: uso sustentável na construção civil. Piracicaba: IPT; 2009.

Jankowsky IP, Chimelo JP, Cavancante AA, Galina ICM, Nagamura JCS. Madeiras brasileiras. Caxias do Sul: Spectrum; 1990. 172 p.

Kraus JE, Arduin M. Manual básico de métodos em morfologia vegetal. Seropédia: EDUR; 1997.

Kretschmann DE. Mechanical properties of wood. In: Forest Products Laboratory. Wood handbook: wood as an engineering material. Madison: Forest Products Laboratory; 2010. chap. 5.

Laboratório de Tecnologia da Madeira - LTM. Base de dados do Laboratório de Tecnologia da Madeira. Curitiba: UFPR; 2009.

Latorraca JVF, Souza MT, Silva LDSAB, Ramos LMA. Dendrocronologia de árvores de Schizolobium parahyba(Vell.) S. F. Blake de ocorrência na ReBio de Tinguá-RJ. Revista Árvore 2015; 39(2): 385-394. http:// dx.doi.org/10.1590/0100-67622015000200018.

Leonello EC, Avaliação das propriedades físico-mecânicas da madeira de árvores de Hevea brasiliensis em três condições de sanidade no Estado de São Paulo [dissertation]. Botucatu: Faculdade de Ciências Agronômicas, UNESP; 2011.

Lima JPC, Mello JA Fo, Freire LR, Vieira F. Nitrogen uptake for Schizolobium parahyba (Vell.) Blake in greenhouse phase in three environments. Floresta e Ambiente 2000; 7(1): 11-18.

Mainieri C, Chimelo JP. Fichas de caracteristicas das madeiras brasileiras. São Paulo: IPT; 1989. 418 p. (Publicação IPT; no. 1791).

Marcati CR, Milanez CRD, Machado SR. Seasonal development of secondary xylem and phloem in Schizolobium parahyba (Vell.) Blake (Leguminosae: Caesalpinioideae). Trees 2008; 22(1): 3-12. http://dx.doi.org/10.1007/s00468-007-0173-8.

Mattos BD, Missio AL, Cademartori PHG, Gatto DA, Magalhães WLE. Color changes of wood from Pinus taeda and Schizolobium parahyba treated by in situ polymerization of methyl methacrylate using crosslinkers. Maderas Ciencia y Tecnología 2016; 18(1): 113-124.

Mendes MM, Oliveira CF, Lopes DS, Vale LH, Alcântara TM, Izidoro LF et al. Anti-snake venom properties of Schizolobium parahyba (Caesalpinoideae) aqueous leaves extract. Phytotherapy Research 2008; 22(7): 859-866. http:// dx.doi.org/10.1002/ptr.2371. PMid:18567056.

Nisgoski S, Muñiz GIB, Trianoski R, Matos JLM, Venson I. Anatomical characteristics of wood and resistance indices of Schizolobium parahyba (Vell.) Blake paper from experimental planting. Scientia Forestalis 2012; 40(94): 203-211.

Nock HP, Richter HG, Burger LM. Tecnologia da madeira. Curitiba: UFPR; 1975. 21 p.

Nogueira MCJA. Indicações para o emprego de dezesseis espécies de eucalipto na construção civil [dissertation]. São Carlos: Escola de Engenharia de São Carlos, Universidade de São Paulo; 1991.

Pimentel-Gomes F. Curso de estatistica experimental. Piracicaba: ESALQ, USP; 1985.

Richter HG, Tomaselli I, Moreschi JC. Guapuruvu technological study (Schizolobium parahyba). Part 2: plywood manufacturing. Floresta 1975; 6(1): 14-23.

Ruelle J, Beauchêne J, Yamamoto H, Thibaut B. Variations in physical and mechanical properties between tension and opposite wood from three tropical rainforest species. Wood Science and Technology 2011; 45(2):339-357. http:// dx.doi.org/10.1007/s00226-010-0323-9.

Sales A. Proposição de classes de resistência para madeira[thesis]. São Paulo: Escola Politécnica, Universidade de São Paulo; 1996.

Salgado ALB, Ciaramello D, Azzini A. The guapuruvu: development, productivity and cellulosic characteristics. O Agronômico 1989; 41(2): 104-109. 
Sousa LC. Caracterização da madeira de tração em Eucalyptus grandis e sua influência na produção de polpa celulósica [dissertation]. Viçosa: Universidade Federal de Viçosa; 2004.

Vale LHF, Mendes MM, Fernandes RS, Costa TR, HageMelim LI, Sousa M et al. Protective effect of Schizolobium parahyba flavonoids against snake venoms and isolated toxins. Current Topics in Medicinal Chemistry 2011; 11(20): 2566-2577. http://dx.doi.org/10.2174/156802611797633438. PMid:21682680.
Vital BR. Métodos de determinação da densidade da madeira. Viçosa: Sociedade de Investigações Florestais; 1984. 21 p. (Boletim Técnico, no. 1).

Williamson GB, Wiemann MC, Geaghan JP. Radial wood allocation in Schizolobium parahyba. American Journal of Botany 2012; 99(6): 1010-1019. http://dx.doi.org/10.3732/ ajb.1100516. PMid:22575368.

Zhang SY, Koubaa A. Wood characteristics, processing and end-uses of Tamarack. Quebec: Forintek Canada Corp Report; 2001. 